\title{
microRNA in Patients with Hepatitis B and Hepatitis C Virus Associated Hepatocellular Carcinoma and Cirrhosis
}

\author{
Hepatit B ve Hepatit C Ilișkili Hepatosellüler Karsinom ve Siroz Olgularında microRNA
}

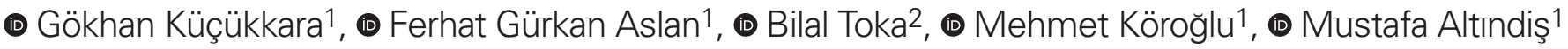 \\ 1 Sakarya University Faculty of Medicine, Department of Microbiology, Sakarya, Turkey \\ 2Sakarya University Faculty of Medicine, Department of Internal Medicine and Gastroenterology, Sakarya, Turkey
}

\begin{abstract}
Objectives: The aim of this study was to determine the potentials of hsa-microRNAs (miRNA)-21-3p, hsa-miRNA-29a-3p, hsa-miRNA122-3p, hsa-miRNA-192-5p in Hepatitis B (HBV) and HCV related hepatocellular carcinoma $(\mathrm{HCC})$ and liver cirrhosis $(\mathrm{LC})$ cases, being biomarkers by examining their levels.

Materials and Methods: Sixty patients and 26 healthy volunteers were included in the study. Total RNA isolation in the serum samples was performed with the Direct-zol ${ }^{\mathrm{TM}}$ RNA MiniPrep (Zymo Research Corp., USA) commercial kit followed by cDNA synthesis and realtime polymerase chain reaction amplification with EPIK miRNA Select Hi/Lo-ROX (Bioline Reagents Ltd., USA). For amplification and analysis, Rotor-Gene Q (QIAGEN, Germany) instrument was used and statistical analyzes were performed with SPSS 21 (IBM, USA) program.

Results: Hsa-miRNA-21-3p and hsa-miRNA-122-3p levels increased 3-4 fold in patients without HCV related LC (HCV-LC) and hsamiRNA-29a-3p expression in HCV infected patients has significantly decreased $(p<0.05)$. hsa-miRNA-192-5p showed a 3-fold increase in HBV related LC (HBV-LC) group $(\mathrm{p}<0.05)$ but not in other groups. The hsa-miRNA-122-3p value is increased in HCV-LC patients. Conclusion: In our study, miRNA-21-3p and hsa-miRNA-122 for HBV-HCC and HCV-HCC diseases; hsa-miRNA-21-3p, hsamiRNA-122 and hsa-miRNA-192-5p for HBV-LC; miRNA-29a-3p test for HCV-LC could be used as diagnostic markers.

Keywords: miRNA, hepatitis, hepatocellular carcinoma and cirrhosis
\end{abstract}

\section{ÖZ}

Amaç: Bu çalışmada hsa-mikroRNA (miRNA)-21-3p, hsa-miRNA29a-3p, hsa-miRNA-122-3p, hsa-miRNA-192-5p'nin Hepatit B (HBV) ve HCV ilişkili hepatosellüler karsinoma $(\mathrm{HCC})$ ve karaciğer sizrozu (KS) olgularındaki düzeyleri incelenerek, biyobelirteç olma potansiyellerinin belirlenmesi amaçlanmıştır.

Gereç ve Yöntemler: Çalışmaya 60 hasta ve 26 sağlıklı gönüllü dahil edilmiștir. Serum örneklerinde total RNA izolasyonu, Direct-zol ${ }^{\mathrm{TM}}$ RNA MiniPrep (Zymo Research Corp., USA) ticari kiti ile yapıldıktan sonra cDNA sentezi ve gerçek zamanlı polimeraz zincir reaksiyonu amplifikasyonu EPIK miRNA Select Hi/Lo-ROX (Bioline Reagents Ltd., USA) ile gerçekleştirilmiştir. Amplifikasyon ve analizler için Rotor-Gene Q (QIAGEN, Germany) cihazı kullanılmış, istatistiksel analizler SPSS 21 (IBM, USA) programı ile yapılmıştır.

Bulgular: Hsa-miRNA-21-3p ve hsa-miRNA-122-3p seviyeleri HCV ilişkili KS dışındaki hasta gruplarında 3-4 kat oranında artışlar göstermiş, HCV enfeksiyonlu hastalarda hsa-miRNA-29a-3p ekspresyonunda anlamlı azalmalar saptanmıştır $(p<0.05)$. hsamiRNA-192-5p ise HBV ilişkili KS grubunda 3 kat artış gösterirken $(p<0.05)$ diğer gruplarda belirgin farklılıklar göstermemiştir. hsamiRNA-122-3p değeri, HCV-KS hastalarında artmıştır.

Sonuç: Çalışmamızda, tanı belirteçleri olarak; HBV ilişkili HCC ve HCV ilişkili HCC için hsa-miRNA-21-3p ve hsa-miRNA-122, HBV ilişkili KS için hsa-miRNA-21-3p, hsa-miRNA-122 ve hsa-miRNA192-5p, HCV-KS için miRNA-29a-3p testlerinin kullanılabileceği belirlenmiştir.

Anahtar Kelimeler: miRNA, hepatit, hepatosellüler karsinom ve siroz

Küçükkara G, Aslan FG, Toka B, Köroğlu M, Altındiş M. microRNA in Patients with Hepatitis B and Hepatitis C Virus Associated Hepatocellular Carcinoma and Cirrhosis. Viral Hepat J. 2019;25:113-116.

Address for Correspondence: Ferhat Gürkan Aslan MD, Sakarya University Faculty of Medicine, Department of Microbiology, Sakarya, Turkey Phone: +90 5432912980 E-mail: ferhatgurkan33@hotmail.com ORCID ID: orcid.org/0000-0001-8394-1962 Received: 4.07.2019 Accepted: 21.09.2019

${ }^{(C)}$ Copyright 2019 by Viral Hepatitis Society / Viral Hepatitis Journal published by Galenos Publishing House. 


\section{Introduction}

Hepatitis B virus (HBV) and HCV viruses are etiologic factors that cause liver damage. It is estimated that approximately 5 percent of the world's population has chronic HBV infection (approximately 350 million people). The prevalence of global HCV is approximately $2 \%$ and 180 million people are persistent $\mathrm{HCV}$ carriers. However, HBV/HCV infection rates vary from country to country. A significant percentage of chronic HBV and HCV carriers develop necroinflammatory liver diseases of different severity and course patterns such as persistent injury, cirrhosis, hepatic insufficiency and hepatocellular carcinoma (HCC) (1).

High morbidity and mortality rates of $\mathrm{HCC}$ require more specific methods and more effective strategies for diagnosis and treatment. Laboratory tests and imaging techniques such as ultrasonography along with histopathology, computed tomography and magnetic resonance are often used to diagnose it (2). All these diagnostic tools are limited due to their cost, availability and reproducibility (3). Therefore, some serum or tissue biomarkers, such as microRNAs (miRNAs), have been developed for clinical applications in recent years (1).

miRNAs are oligonucleotides of small non-coding RNA structure of 18-24 nucleotides (average $22 \mathrm{nt}$ ) transcribed from highly conserved DNA regions but not translated into protein. miRNAs play a crucial role in the processing, regulation and similar post-transcriptional levels of intracellular genetic information in all multicellular eukaryotic organisms $(4,5,6)$. miRNAs are involved in numerous pathways that are critical for the cell, and therefore, when they fail to function, they may lead to susceptibility to diseases, particularly cancer (7).

There has been a recent increase in the number of studies that investigate the role of miRNAs in regulating different cellular processes such as energy production, protein synthesis, proliferation, differentiation and apoptosis (8). In the onset and progression of cancer, miRNAs act as tumor suppressors or oncogenes depending on the characters of target genes (4). Disruption of normal miRNA expression patterns has been reported in different liver diseases ranging from chronic hepatitis $(\mathrm{CHB})$ to cirrhosis and HCC $(9,10,11)$. Diagnosing people with HCC at an early stage before clinical signs and symptoms develop is an urgent need for improving prognosis (12).

The aim of this study was to determine hsa-miRNA-21-3p, hsa-miRNA-29a-3p, hsa-miRNA-122-3p and hsa-miRNA-192-5p expression levels in HBV- and HCV-related HCC and liver cirrhosis (LC) cases and their potential to become biomarkers. The miRNAs included in the study were determined by literature review. One miRNA was selected from the well-known change in liver diseases (hsa-miRNA-122-3p), while the other miRNAs were selected from miRNAs, in which studies on this subject have just begun.

\section{Materials and Methods}

\section{Sampling Methods}

The study sample consisted of 60 patients admitted to gastroenterology for treatment and follow-up and of 26 healthy volunteers. Eighteen participants had HBV-associated HCC, 15 had HBV-related cirrhosis, 8 had HCV-associated HCC and 19 participants had HCV-related cirrhosis. The study was approved by the Ethics Committee of the Sakarya University Faculty of Medicine (approval number: 71522473/050.01.04/132 and date: 28.06.2016). Written informed consent was obtained from patients prior to participation. A study group was established from patients who agreed to participate in the study based on their medical and pathology reports.

\section{Preparation and Analysis of Samples}

Blood samples were collected from participants and placed in dry gel tubes. Serums separated from the blood samples were stored at $-80^{\circ} \mathrm{C}$ until total RNA isolation, which was, then, performed using a Direct-zol'TM RNA MiniPrep (ZYMO Research Corp., USA) kit according to the manufacturer's instructions. cDNA synthesis and real-time polymerase chain reaction amplification from the isolate was performed using an EPIK ${ }^{\mathrm{TM}}$ miRNA Select Hi/Lo-ROX (Bioline Reagents Ltd.) miRNA amplification kit. Amplification and analysis were performed using a Rotor-Gene Q (QIAGEN, Germany).

\section{Statistical Analysis}

Data were analyzed using the Statistical Package for Social Sciences (IBM SPSS Statistics 20, USA) at a significance level of 0.05 . Recently, it has been proposed that the change in gene expression in a microarray experiment will be best defined by using fold change rather than t-statistic. Fold change is the ratio of two values and measures how much of a variable changes between the two measurements. The difference in the mean obtained by taking the logarithm of the data corresponds to the proportions of the original scale $(13,14)$.

\section{Results}

Table 1 shows some demographic and clinical data of the participants. Patients' hsa-miRNA-21-3p, hsa-miRNA-29a-3p, hsamiRNA-122-3p and hsa-miRNA-192-5p expression levels were evaluated as multiples of those of the control group (Table 2).

Hsa-miRNA-21-3p and hsa-miRNA-122-3p levels of all patient groups, except HCV-LC patients, increased 3-4 fold. hsa-miRNA-

\begin{tabular}{|c|c|c|}
\hline & $\mathrm{n}$ & Mean \\
\hline Age (years) & 60 & 62.15 \\
\hline Urea (mg/dL) & 60 & 57.48 \\
\hline Uric acid $(\mathrm{mg} / \mathrm{dL})$ & 60 & 5.68 \\
\hline Glucose (mg/dL) & 60 & 140.9 \\
\hline Cholesterol (mg/dL) & 60 & 152.92 \\
\hline Triglyceride $(\mathrm{mg} / \mathrm{dL})$ & 60 & 119.23 \\
\hline ALT (U/L) & 60 & 37.70 \\
\hline AST (U/L) & 60 & 68.05 \\
\hline AFP Log $10(\mathrm{ng} / \mathrm{mL})$ & 60 & 3.47 \\
\hline T-Bilirubin (mg/dL) & 60 & 2.21 \\
\hline D-Bilirubin (mg/dL) & 60 & 0.92 \\
\hline HBV-DNA (IU/mL) & 33 & 764621.15 \\
\hline HCV-DNA (IU/mL) & 27 & 165.23 \\
\hline
\end{tabular}




\begin{tabular}{l}
$\begin{array}{l}\text { Table 2. hsa-miRNA-21-3p, hsa-miRNA-29a-3p, hsa-miRNA-192-5p and hsa-miRNA-122-3p expression levels in HBV and HCV-related hepatocellular } \\
\text { carcinoma and cirrhosis cases }\end{array}$ \\
\hline
\end{tabular}

29a-3p expression significantly decreased in patients with HCV infection $(p<0.05)$. hsa-miRNA-192-5p increased 3-fold in HBV-LC patients $(p<0.05)$ but showed no significant difference in other groups. hsa-miRNA-122-3p, which is a liver specific miRNA, increased in HCV-LC patients.

\section{Discussion}

$\mathrm{HCC}$ is an aggressive malignancy with poor prognosis and high mortality rates worldwide. It, however, does not have a reliable and effective and non-invasive biomarker. We, therefore, need new biomarkers to determine HCC early. miRNA expression levels are promising biomarkers, and therefore, are of great interest (15). However, numerous studies on $\mathrm{CHB}$ characterize miRNA profiles as controversial and complex.

Ebrahimifard et al. (16) showed that miRNA-122 can be used as a biomarker to detect cirrhosis associated with $\mathrm{CHB}$ and $\mathrm{HBV}$ before progressing to HCC. We also detected a more significant increase in miRNA 122-3p in the hepatitis B-related HCC and LC groups and in the HCV-related HCC group compared to the healthy control group.

Lin et al. (17) reported that miRNA-29a, miRNA-122 and miRNA-192 synthesis was 2.64, 3.13 and 2.60 times, respectively, higher in patients with $\mathrm{HCC}$ than in those diagnosed with $\mathrm{CHB}$. Zhou et al. (18) conducted a study on plasma samples of HBVrelated HCC patients and reported a 3.3-, 2- and 2.9-fold increase in miRNA-122, miRNA-21 and miRNA-192, respectively. We also detected 1.4-, 1.48-, 2.54- and 3.67-fold increase in miRNA-29a-3p, miRNA-192-5p, miRNA-122 and miRNA-21, respectively, in HBVrelated HCC patients. Tan et al. (19) developed a miRNA panel for HCC diagnosis and reported that miRNA-122 and miRNA-192 synthesis was 0.27 and 0.76 times lower in patients diagnosed with HCC than in healthy volunteers.

Wang et al. (20) conducted a study on 30 patients with HCC and 30 patients with $\mathrm{CHB}$ and 30 healthy volunteer participants in Xinxiang, China and reported that patients with $\mathrm{HCC}$ had a higher serum miR-21 expression level than CHB or healthy volunteers, which is consistent with miRNA-21 values in our study (20).

Zekri et al. (21) reported that miRNA-122 and miRNA-192 expression was, respectively, 2.2 and 1.88 times higher in HCVinfected patients with HCC than in healthy volunteers. We also detected that miRNA-122 and miRNA-192 upregulation was 3.84 and 1.88 times higher in HCV-related HCC patients than in healthy participants.

Zhou et al. (18) reported that miRNA-122, miRNA-21 and miRNA-192 expression was, respectively, 1.9, 1.2 and 4.6 times higher in patients with HCC than in cirrhosis patients. Tan et al.
(19) conducted a study in China and reported that cirrhosis patients had 2 and 1.2 times higher miRNA-122 and miRNA-192 levels, respectively, than patients with HCC. They also reported that miRNA-21 and miRNA-122 synthesis was, respectively, 1.6 and 3.13 times higher in cirrhotic patients than in patients with HCC. We also detected that patients with HCC had higher miRNA122 and miRNA-192 synthesis than cirrhosis patients. However, miRNA-21 expression was 4.7 times higher in HBV-related LC patients and 0.74 times less in HCV-related LC patients.

Bao et al. (22) conducted a study on serum samples and reported a downregulation in fibrosis-related miRNA-29 and miRNA-21 expression. We also detected a downregulation in miRNA-29a-3p expression in HCV-related HCC and LC patients, a downregulation in miRNA-21-3p expression only in HCV-related LC patients and a 1.14-fold increase in miRNA-29a-3p expression in HBV-related LC patients.

Again, Zekri et al. (21) reported a 0.45- and 1.17-fold change in miRNA-122 and miRNA-192 levels in the serums of cirrhosis patients with $\mathrm{HCV}$ infection than in those of healthy control group. We also detected a 0.52-fold downregulation in miRNA-122 and a 1.02-fold upregulation in miRNA-192 in HCV-related LC patients and a 2.98-fold increase in miRNA-192-5p in HBV-related LC patients.

Oksuz et al. (23) reported that miRNA-29a-3p synthesis was 2.95 times lower and miRNA-122 synthesis was 5.22 times higher in HCC patients whereas miRNA-122 synthesis was 1.38 times lower in cirrhosis patients. The results of miRNA-29a reported by Oksuz et al. (23) are different from ours. In our study, MiRNA-29a synthesis was 1.41 and 0.40 times in HBVr-related HCC patients and HCV-related HCC patients, respectively. miRNA-122 synthesis was 2.54 and 3.83 fold in HBV-HCC and HCV-HCC patients, respectively. miRNA-122 synthesis was 0.5 -fold in HCV-LC patients.

Having conducted a study on individuals with HCV infection, Waring et al. (24) detected more than 100 miRNA species in serum and found that miRNA-122 level showed the most consistent change in all HCV genotypes in response to treatment. They also reported that miRNA-122 decreased approximately four-fold in two weeks and remained low throughout the treatment in all participants.

Tat Trung et al. (25) stated that mir-21, mir-122 and mir-192 as well as alpha-fetoprotein (AFP) are biomarkers for the diagnosis of HCC in HBV patients, and in particular in HBV-related LC patients with normal AFP levels or in HCC patients with small tumors.

\section{Conclusion}

After a quarter century of research, our knowledge of the mechanisms of biosynthesis, effect and function of miRNAs has 
been greatly enhanced. Depending on the target mRNA, miRNAs act as tumor suppressors or oncogenes in cancer development. Information on miRNAs should be standardized to be able to use them as biomarkers for cancer development. According to our results, hsa-miRNA-21-3p and hsa-miRNA-122 assays can be used for HBV-HCC and HCV-HCC diseases; Hsa-miRNA-21-3p, hsa-miRNA-122 and hsa-miRNA-192-5p assays can be used for HBV-LC and MiRNA-29a-3p assay can be used for HCV-LC. Further research should be conducted to verify these results to accelerate the applicability of the assays.

Acknowledgment; This study, executed by Mustafa Altındiş, Sakarya University, supported by the Coordination Scientific Research Projects (project no. SAA 2017-08-06-027 BAP), which won awards presented at the 2018 convention VHSD.

\section{Ethics}

Ethics Committee Approval: The study was approved by the Ethics Committee of the Sakarya University Faculty of Medicine (approval number: 71522473/050.01.04/132 and date: 28.06.2016).

Informed Consent: Written informed consent was obtained from patients prior to participation.

Peer-review: Externally and internally peer-reviewed.

\section{Authorship Contributions}

Concept: M.A., G.K., F.G.A., Design: M.A., FG.A., B.T., Data Collection or Processing: G.K., FG.A., B.T., Analysis or Interpretation: G.K., F.G.A., M.A., M.K., Literature Search: G.K., M.A., F.G.A., Writing: G.K., M.A., M.K., FG.A.

Conflict of Interest: No conflict of interest was declared by the authors.

Financial Disclosure: This study was supported by Sakarya University Scientific Research Projects Coordinator(BAPK).

\section{Refernces}

1. Fiorino $\mathrm{S}$, Bacchi-Reggiani $\mathrm{ML}$, Visani $\mathrm{M}$, Acquaviva $\mathrm{G}$, Fornelli $\mathrm{A}$, Masetti M, Tura A, Grizzi F, Zanello M, Mastrangelo L, Lombardi R, Di Tommaso L, Bondi A, Sabbatani S, Domanico A, Fabbri C, Leandri P, Pession A, Jovine $E$, de Biase D. MicroRNAs as possible biomarkers for diagnosis and prognosis of hepatitis Band C-related-hepatocellular-carcinoma. World J Gastroenterol. 2016;22:3907-3936

2. Attwa $\mathrm{MH}, \mathrm{El}$-Etreby SA. Guide for diagnosis and treatment of hepatocellular carcinoma. World J Hepatol. 2015;7:1632-1651.

3. Bodzin AS, Busuttil RW. Hepatocellular carcinoma: Advances in diagnosis, management, and long term outcome. World J Hepatol. 2015;7:1157-1167.

4. Saydam F, Değirmenci I, Güneş HV. MicroRNAs and cancer. Dicle Medical Journal. 2011;38:113-120.

5. Bartel DP. MicroRNAs: Target recognition and regulatory functions. Cell. 2009;136:215-233.

6. Feng $W$, Feng Y. MicroRNAs in neural cell development and brain diseases. Sci China Life Sci. 2011:54:1103-1112.

7. Thirion M, Ochiya T. Roles of microRNAs in the hepatitis B virus infection and related diseases viruses. 2013;5:2690-2703.

8. Takasaki S. Roles of microRNAs in cancers and development Methods Mol Biol. 2015:1218:375-413.

9. Galasso M, Sandhu SK, Volinia S. MicroRNA expression signatures in solid malignancies. Cancer J. 2012;18:238-243.
10. Lynam-Lennon N, Maher SG, Reynolds JV. The roles of microRNA in cancer and apoptosis. Biol Rev Camb Philos Soc. 2009;84:5571.

11. Nana-Sinkam SP, Croce CM. Clinical applications for microRNAs in cancer. Clin Pharmacol Ther. 2013;93:98-104.

12. Piva R, Spandidos DA, Gambari R. From microRNA functions to microRNA therapeutics: novel targets and novel drugs in breast cancer research and treatment (Review). Int J Oncol. 2013;43:985-994

13. ht t p s://pdfs. $s$ e mantics cholar.org/ a a 2 e/3a 6 bf 641 ec 42 b 67 bdd 823 ef 218 b $8 c d d d 336$ e. pdf?_ga=2.47297316.2071923663.15665896891470918111.1566589689

14. https://ncss-wpengine.netdna-ssl.com/wp-content/themes/ncss/ pdf/Procedures/PASS/Tests_for_Fold_Change_of_Two_Means.pdf

15. Chen S, Chen H, Gao S, Qiu S, Zhou H, Yu M, Tu J. Differentia expression of plasma microRNA-125b in hepatitis B virus-related liver diseases and diagnostic potential for hepatitis B virusinduced hepatocellular carcinoma. Hepatol Res. 2017;47:312-320.

16. Ebrahimifard M, Zandi M, Moradi A. Evaluation of miR-122 levels in chronic HBV and liver cirrhosis patients. Arch Med Lab Sci. 2016;2:108-110

17. Lin XJ, Chong Y, Guo ZW, Xie C, Yang XJ, Zhang Q, Li SP, Xiong $Y$, Yuan $Y$, Min J, Jia WH, Jie $Y$, Chen MS, Chen MX, Fang JH, Zeng C, Zhang Y, Guo RP, Wu Y, Lin G, Zheng L, Zhuang SM. A serum microRNA classifier for early detection of hepatocellular carcinoma: a multicentre, retrospective, longitudinal biomarker identification study with a nested case-control study. Lancet Oncol. 2015;16:804-815.

18. Zhou J, Yu L, Gao X, Hu J, Wang J, Dai Z, Wang JF, Zhang Z, Lu S, Huang $X$, Wang Z, Qiu S, Wang X, Yang G, Sun H, Tang Z, Wu Y, Zhu H, Fan J. Plasma microRNA panel to diagnose hepatitis B virus-related hepatocellular carcinoma. J Clin Oncol. 2011;29:4781-4788

19. Tan $Y$, Pan $T, Y e Y, G e$ G, Chen L, Wen D, Zou S. Serum microRNAs as potential biomarkers of primary biliary cirrhosis. PLoS One. 2014;9:e111424.

20. Wang $S$, Qiu L, Yan $X$, Jin W, Wang $Y$, Chen L, Wu E, Ye $X$, Gao GF, Wang F, Chen Y, Duan Z, Meng S. Loss of microRNA 122 expression in patients with hepatitis $B$ enhances hepatitis $B$ virus replication through cyclin $\mathrm{G}(1)$-modulated P53 activity. Hepatology. 2012;55:730-741

21. Zekri AN, Youssef AS, El-Desouky ED, Ahmed OS, Lotfy MM Nassar AA, Bahnassey AA. Serum microRNA panels as potential biomarkers for early detection of hepatocellular carcinoma on top of HCV infection. Tumour Biol. 2016;37:12273-12286.

22. Bao S, Zheng J, Li N, Huang C, Chen M, Cheng Q, Yu K, Chen S, Zhu M, Shi G. Serum MicroRNA levels as a noninvasive diagnostic biomarker for the early diagnosis of hepatitis B virus-related liver fibrosis. Gut Liver. 2017;11:860-869.

23. Oksuz Z, Serin MS, Kaplan E, Dogen A, Tezcan S, Aslan G, Emekdas G, Sezgin O, Altintas E, Tiftik EN. Serum microRNAs; miR-30c-5p, miR-223-3p, miR-302c-3p and miR-17-5p could be used as novel non-invasive biomarkers for HCV-positive cirrhosis and hepatocellular carcinoma. Mol Biol Rep. 2015;42:713-720.

24. Waring JF, Dumas EO, Abel S, Coakley E, Cohen DE, Davis JW, Podsadecki T, Dutta S. Serum miR-122 may serve as a biomarker for response to direct acting antivirals: effect of paritaprevir/R with dasabuvir or ombitasvir on miR-122 in HCV-infected subjects. J Viral Hepat. 2016;23:96-104.

25. Tat Trung N, Duong DC, Tong HV, Hien TTT, Hoan PQ, Bang MH, Binh MT, Ky TD, Tung NL, Thinh NT, Sang VV, Thao LTP, Bock CT, Velavan TP, Meyer CG, Song LH, Toan NL. Optimisation of quantitative miRNA panels to consolidate the diagnostic surveillance of HBV-related hepatocellular carcinoma. PLoS One. 2018:13:e0196081. 